Goldschmidt 2021 Abstract

https://doi.org/10.7185/gold2021.4258

\section{Determining the style and provenance of magmatic activity during the Early Aptian Oceanic Anoxic Event (OAE}

\section{1a)}

\author{
LAWRENCE PERCIVAL ${ }^{1}$, LEONARDO RIBEIRO \\ TEDESCHI $^{2}$, ROBERT CREASER ${ }^{3}$, CINZIA BOTTINI $^{4}$, \\ ELISABETTA ERBA ${ }^{4}$, FABIENNE GIRAUD ${ }^{5}$, HENRIK \\ SVENSEN $^{6}$, JAIRO SAVIAN $^{7}$, RICARDO TRINDADE $^{8}$, \\ RODOLFO COCCIONI ${ }^{9}$, FABRIZIO FRONTALINI ${ }^{9}$, LUIGI \\ JOVANE $^{10}$, TAMSIN A. MATHER ${ }^{11}$ AND HUGH \\ JENKYNS $^{12}$
}

${ }^{1}$ Vrije Universiteit Brussel

${ }^{2}$ Petróleo Brasileiro

${ }^{3}$ University of Alberta

${ }^{4}$ Università degli Studi di Milano

${ }^{5}$ Université Grenoble Alpes

${ }^{6}$ University of Oslo

${ }^{7}$ Universidade Federal do Rio Grande do Sul

${ }^{8}$ Universidade de São Paulo

${ }^{9}$ Università degli Studi di Urbino

${ }^{10}$ Oceanographic Institute, University of São Paulo

${ }^{11}$ University of Oxford

${ }^{12}$ Department of Earth Sciences, University of Oxford

Presenting Author: lawrence.percival@vub.be

The Early Aptian Oceanic Anoxic Event (OAE 1a: 120 Ma) marked a time of pronounced environmental change, which was characterised by the development of oxygen-depleted conditions throughout much of the global ocean, with climate warming, ocean acidification, enhanced continental weathering, and biospheric crises also proposed as having occurred. Major emissions of (isotopically light) carbon to the ocean-atmosphere system are widely considered to have caused these changes, as evidenced by carbon-isotope excursions recorded in basal OAE 1a sediments worldwide, but the precise source of this carbon remains debated. Volcanic $\mathrm{CO}_{2}$ emissions related to the emplacement of the Greater Ontong-Java Plateau (G-OJP) are frequently advocated as the ultimate trigger of the OAE, based on closely matching ages of the event and G-OJP basalts. However, it is unclear whether magmatic carbon alone could have been the sole cause of the OAE and negative carbon-isotope excursion. In recent years, dating of High Arctic Large Igneous Province (HALIP) rocks has led to proposals that magmatic sill intrusion into volatile-rich sediments could have generated thermogenic carbon as an alternative/supplementary trigger.

This study combines the first global-scale dataset of sedimentary mercury $(\mathrm{Hg})$ enrichments for OAE $1 \mathrm{a}$ (which has previously only been studied in the NW Tethys) with new and published osmium-isotope $\left({ }^{187} \mathrm{Os} /{ }^{188} \mathrm{Os}\right)$ data to investigate the dominant style of volcanism operating throughout the event. A clear $\mathrm{Hg}$ peak coeval with a shift to unradiogenic ${ }^{187} \mathrm{Os} /{ }^{188} \mathrm{Os}$ in basal OAE 1a strata is documented only in one Pacific site very proximal to the G-OJP, whilst Arctic, Atlantic, and Tethyan records either show no mercury enrichment, or a lowermagnitude one higher in the OAE 1a stratigraphy. Based on the different residence times of Os and $\mathrm{Hg}$ in the modern ocean, this contrasting pattern of $\mathrm{Hg}$ and ${ }^{187} \mathrm{Os} /{ }^{188} \mathrm{Os}$ trends is interpreted to reflect intense submarine volcanism on the G-OJP at the onset of OAE 1a, with more widespread mercury-cycle perturbations (possibly linked to HALIP) only occurring later in the event. These findings confirm the G-OJP as the primary trigger of OAE 1a, suggesting that at least some LIPs are capable of causing major carbon-cycle disturbances via magmatic $\mathrm{CO}_{2}$ emissions alone. 